\title{
Application of Iron High-selectivity Solid Phase Extraction Resin to Simultaneous Determination of Trace Elements in High- purity Iron by ICP-MS
}

\author{
Hidekazu Tsukahara ${ }^{1)^{*}}$ and Yoichi NAKASHIMA ${ }^{1)}$ \\ 1) Osaka Research Institute of Industrial Science and Technology
}

Abstract: In this study, we developed a separation method to extract iron from steel solutions using a solid phase extraction resin to determine the composition of trace elements in high-purity steel, with the aid of inductively coupled plasma mass spectrometry (ICP-MS). The acidic solution of steel was passed through the resin and amounts of the trace elements were determined by analyzing the eluate. To obtain optimum analytical conditions, maximum amount of iron was extracted into the resin and the effects of the acid species used to decompose the steel, and their concentrations were examined. Methods to reuse the resin were also investigated. Under optimal conditions, the quantities of many elements such as $\mathrm{Mn}, \mathrm{Ni}, \mathrm{Cr}$, $\mathrm{Cu}, \mathrm{Co}, \mathrm{Al}, \mathrm{As}, \mathrm{Bi}, \mathrm{Mg}, \mathrm{Ce}, \mathrm{La}, \mathrm{Se}, \mathrm{Pb}, \mathrm{Sb}, \mathrm{Te}, \mathrm{Zn}$, and $\mathrm{Cd}$ were determined. However, some elements such as Mo, Sn, and W, which were dissolved as oxyacid anions, were extracted into the resin, in addition to iron. The estimated amounts of trace elements in reference materials of high-purity steel were found to be in good agreement (in the order of $\mu \mathrm{g} / \mathrm{g}$ ) with the certified values.

Keywords: solid phase extraction; iron high selectivity molecular recognition resin; high-purity iron; trace elements; ICP-MS.

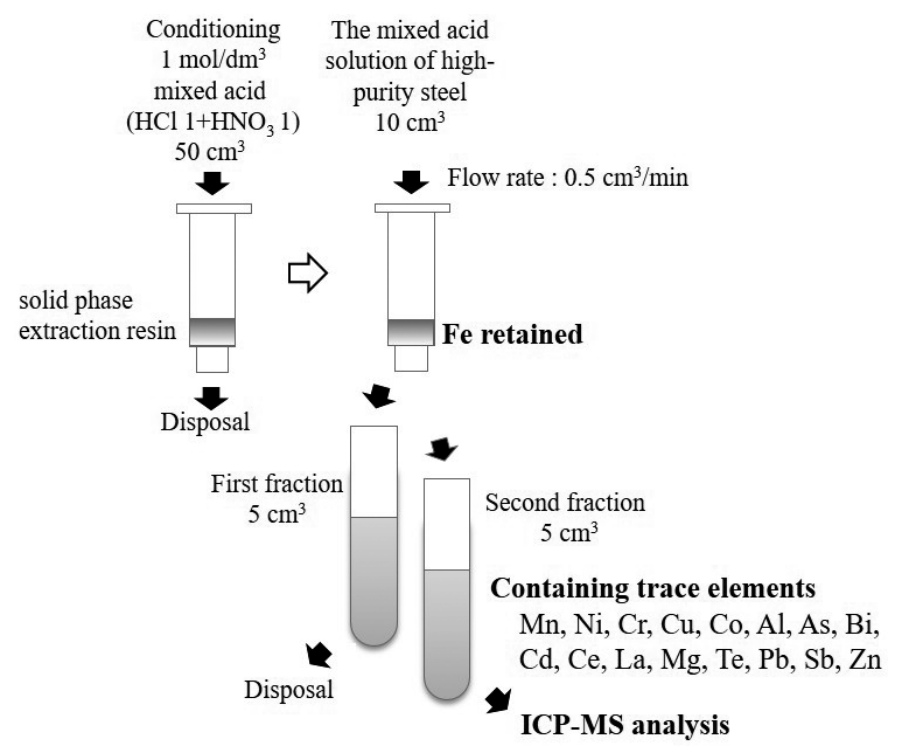




\title{
ICP-MSによる高純度鉄中微量元素の同時定量における 鉄高選択性固相抽出樹脂の応用
}

\author{
塚原 秀和 ${ }^{1) *} \cdot$ 中島 陽一 ${ }^{11}$ \\ Application of Iron High-selectivity Solid Phase Extraction Resin to Simultaneous Determination \\ of Trace Elements in High-purity Iron by ICP-MS \\ Hidekazu Tsukahara and Yoichi Nakashima
}

\section{1. 緒言}

最近, 鉄鋼材料の高機能化, 高純度化とともに, 含有微 量元素の高感度，高精度分析の要望が高くなっている ${ }^{1,2)}$ 。 $\mu \mathrm{g} / \mathrm{g}$ オーダーでの元素分析では, 主成分である鉄が分析感 度の低下や測定対象元素への干渉を引き起こすため, 鉄 と測定目的元素との分離が行われることが多い。分離手 法は, 測定対象元素を選択的に捕集し系外へ取り出すも のと，鉄のみを取り除き，測定目的元素を溶液内に残存さ

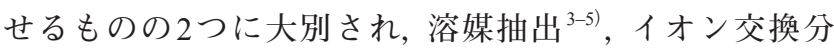
離 $^{6-9)}$, 共沈分離 ${ }^{10)}$, 固相抽出分離 ${ }^{11-13)}$ など様々な方法が試 みられている。

主成分の鉄を分離する手法としては4-メチル-2-ペンタ ノン（MIBK）を用いた溶媒抽出法 ${ }^{14-16)}$ により高濃度塩酸 溶液から有機相に鉄を分離し，水相の残留元素を分析する 手法が広く用いられている。この手法では，高マトリック スである鉄を取り除いた水溶液をそのまま測定できるとい う利点を有する。しかし, 煩雑であり, 操作環境からの污 染を受けやすいなど, 操作に関する熟練性が求められる。 加えて, 鉄量増加に従い MIBKも多量に必要となることや, 有機溶媒による人体への影響などの問題がある。また，近 年, 熟練分析技術者の減少による分析のスキリフリー化, 簡便化が課題となっている。

このような課題を解決するため, 固相抽出樹脂を用いた 分析手法の研究開発が行われている。固相抽出分離では, イミノ二酢酸をはじめとする多種多様な官能基を持つ材 料が開発され，様々な分野で利用されている ${ }^{17)}$ 。その中で 18-クラウン-6では鉛に親和性を持つ性質により鉛選択性 樹脂が開発されており，鉄マトリックスとの分離に使用さ れ, サブ $\mu \mathrm{g} / \mathrm{g}$ オーダーの鉛の分析が行われている ${ }^{18)}$ 。一般 的な固相抽出樹脂を用いた鉄鋼材料の元素分析 ${ }^{19-21)}$ では, 最初に分解溶液を固相樹脂に通液して目的元素のみを捕集 し, 続いて溶離液を通液して目的元素を回収, 測定してい
る。本研究では, 市販されているもののうち $\mathrm{Fe}^{3+}$ イオンを 選択的に分離することが可能な鉄高選択性固相抽出樹脂に 着目した。この固相樹脂に分解溶液を通液して主成分の鉄 を吸着，除去し，樹脂を通過した溶液を直接誘導結合プラ ズマ質量分析 (ICP-MS) により測定することで，簡便に鉄 鋼材料中の微量元素分析を可能とする手法開発を行った。 今回用いた樹脂の大きな特徴としては, $1 \mathrm{~mol} / \mathrm{dm}^{3}$ 程度の酸 濃度での鉄分離が可能な点にある。一般的な ICP-MS 測定 では, 物理干渉, マトリックス干渉などの非スペクトル干 渉や装置への悪影響を防ぐため, 試料中の酸の濃度は最大 $2 \mathrm{~mol} / \mathrm{dm}^{3}$ 程度に制限される ${ }^{22)}$ 。この点から, 高濃度の酸溶 液を用いる従来の固相抽出分離においては分離後の希釈操 作が必須であったが ${ }^{11)}$, この固相抽出樹脂では希釈操作な しにそのまま分析が可能となる。この樹脂を用いて, 高純 度鋼の酸分解溶液に対して分離操作を行い, 鉄の分離およ び，日本鉄鋼認証標準物質高純度鉄シリーズの分析成績表 に記載されている $\mu \mathrm{g} / \mathrm{g}$ オーダーの不純物元素元素中の 28 元素 ( $\mathrm{Si}, \mathrm{Mn}, \mathrm{P}, \mathrm{Ni}, \mathrm{Cr}, \mathrm{Mo}, \mathrm{Cu}, \mathrm{W}, \mathrm{V}, \mathrm{Co}, \mathrm{Ti}, \mathrm{Al}, \mathrm{As}, \mathrm{B}, \mathrm{Bi}, \mathrm{Cd}$, $\mathrm{Ce}, \mathrm{La}, \mathrm{Mg}, \mathrm{Se}, \mathrm{Nb}, \mathrm{Pb}, \mathrm{Sb}, \mathrm{Sn}, \mathrm{Ta}, \mathrm{Te}, \mathrm{Zn}, \mathrm{Zr}$ ) について ICPMS 分析による定量分析に関する研究を行った。

\section{2. 実験}

\section{$2 \cdot 1$ 装置}

分析装置はICP-MS（Thermo Scientific 社製 X series 2) を Table 1 に示す条件下で用いた。Seに関してはコリジョン・ リアクションセル ${ }^{23)}$ を用いて $\mathrm{Ar}$ の干渉を除去して測定を 行った。鉄の除去操作時は, GL Sciences 社製固相カラムを 同社製自然落下マニホールドに装着し, ルアーストップバ ルブ開度を変化させることで抽出速度を調整した。

\section{$2 \cdot 2$ 試薬と器具}

検討のための高純度鉄としては日本鉄鋼連盟日本鉄鋼 認証標準物質JSS003-7を用い, 塩酸, 硝酸（関東化学製 
Ultrapur-100）および過塩素酸（関東化学製原子吸光分析 用）を用いて分解した。水は逆浸透膜により一次処理した 水をMILLIPORE (現Merck) 製Milli-Q Element A10で二次 処理したものを用いた。塩酸・硝酸混合溶液は塩酸，硝酸 および水を体積比 $1 ： 1 ： 2$ の割合で混合することで調製し た。塩酸, 硝酸での分解の際には $50 \mathrm{~cm}^{3}$ 容量のPFA製遠沈 管を用い, ブロックヒーターで加熱した。過塩素酸で分解 する場合は，石英ビーカーを用い，ホットプレート上で王 水分解後, 過塩素酸を加え白煙発生まで加熱した。分解後 の溶液はともにポリプロピレン製遠沈管 GL Sciences 社製 DigiTUBEs $50 \mathrm{~cm}^{3}$ で定容した。

検量線作成用の標準液にはSPEX 社製 ICP 用汎用混合液 XSTC-622Bを用いた。濃度の高い元素およびXSTC-622B に含まれない元素である $\mathrm{Mn}, \mathrm{Ni}, \mathrm{Cr}, \mathrm{Cu}, \mathrm{Co}, \mathrm{Ti}, \mathrm{Al}, \mathrm{B}, \mathrm{Bi}, \mathrm{Ce}$, $\mathrm{La}, \mathrm{Ta}, \mathrm{Te}$ および主成分の鉄の分析においては, 富士フィル ム和光純薬製原子吸光分析用標準液を適時希釈して加えた。

固相樹脂にはシリカ系基体の GL Sciences 社製MetaSEP AnaLig TE- $08^{24)}$ を用いた。この樹脂 $1.5 \mathrm{~g}$ を内径 $1.6 \mathrm{~cm}$, 長 さ $8 \mathrm{~cm}$, 容量 $12 \mathrm{~cm}^{3}$ のカラムに充填し, 溶存鉄の捕集操作 に供した。樹脂の洗浄に同仁科学研究所社製EDTA二アン モニウム塩，キシダ化学製特級アンモニア水を用いた。

\section{$2 \cdot 3$ 操作}

固相樹脂を用いた溶存鉄の捕集操作は以下の手順で行っ た。まず使用する酸のみのブランク溶液 $50 \mathrm{~cm}^{3}$ を自然落下 速度で通液することで樹脂のコンディショニングを行った 後, 分解溶液 $10 \mathrm{~cm}^{3}$ を $0.5 \mathrm{~cm}^{3} / \min$ の速度で通液した。流出 液の最初の $5 \mathrm{~cm}^{3}$ は廃棄し, 残りすべてを回収して分析に 供した。酸濃度が 1 〜 $\mathrm{mol} / \mathrm{dm}^{3}$ の場合はそのまま分析を行 い，それ以上の濃度の場合は水を用いて $1 \mathrm{~mol} / \mathrm{dm}^{3}$ に希釈 したのち，分析を行った。

捕集後の固相樹脂の再生は, $6 \mathrm{~mol} / \mathrm{dm}^{3}$ 塩酸, アンモニア 溶液を用いて $\mathrm{pH}$ を約 8.5 に調整したEDTA二アンモニウム 塩 $10 \mathrm{~g} / \mathrm{dm}^{3}$ 溶液および水それぞれ $10 \mathrm{~cm}^{3}$ を $0.5 \mathrm{~cm}^{3} / \mathrm{min}$ の速 度で通液することで行った。

\section{3. 結果および考察}

\section{$3 \cdot 1$ 最適鉄捕集量の検討}

分析時の鉄の影響を抑えるためには, 樹脂通過後の溶液 中には鉄がほとんど存在しない状況が好ましい。鉄の捕集

Table 1. Operating conditions of ICP-MS

\begin{tabular}{ll}
\hline Parameter & Value \\
\hline RF Power & $1.3 \mathrm{~kW}$ \\
Plasma gas flow (Ar) & $13 \mathrm{dm}^{3} / \mathrm{min}$ \\
Auxiliary gas flow (Ar) & $0.70 \mathrm{dm}^{3} / \mathrm{min}$ \\
Carrier gas flow (Ar) & $0.88 \mathrm{dm}^{3} / \mathrm{min}$ \\
CCT gas flow (7 \% H_2+93\% He) & $6.5 \mathrm{~cm}^{3} / \mathrm{min}$ \\
\hline
\end{tabular}

率がほぼ $100 \%$ となる最適な条件を見出すため, 樹脂の仕 様書による捕集容量 17〜25 mg を指標とし, 塩酸と硝酸の 合計モル濃度が $1 \mathrm{~mol} / \mathrm{dm}^{3}$ となるように調整した塩酸・硝 酸混合溶液液 $10 \mathrm{~cm}^{3}$ 中における鉄量を段階的に変化させ, 通液前後の溶液を分析, 比較することで, 鉄の捕集率変化 を検討した。その結果を Fig.1に示す。樹脂を通過した溶液 中に鉄が存在しない，ほぼ $100 \%$ の捕集率を得るには鉄量 6 $\mathrm{mg}$ が上限であることが分かった。鉄量が $6 \mathrm{mg}$ を超えると， 鉄の捕集量自体は増加するが, 樹脂を通過した溶液中の鉄 濃度も高くなるため, 以後の実験では通液 $10 \mathrm{~cm}^{3}$ 中におけ る鉄量が $5 \mathrm{mg}$ となるように試料量を調整して実験を行っ た。

\section{$3 \cdot 2$ 酸種の検討}

鉄試料分解に用いる酸の種類が，分析に及ぼす影響につ いて検討した。JSS003-7 試料 $25 \mathrm{mg}$ に各元素濃度が $1 \mu \mathrm{g} / \mathrm{g}$ となるよう標準液を添加し，最終濃度が $1 \mathrm{~mol} / \mathrm{dm}^{3}$ となる 量の塩酸, 硝酸, 塩酸 - 硝酸混合溶液および過塩素酸で分 解し, $50 \mathrm{~cm}^{3}$ に定容した。この溶液を用い, 通液前後の溶 液を分析, 比較して, 各元素の固相樹脂での捕集率を求め た。その結果を Table 2 に示す。なお, 元素の表記順は日本 鉄鋼連盟日本鉄鋼認証標準物質，高純度鉄シリーズ 003-7 分析成績表に記載されている元素順とした。ここで特徵的 なのは，塩酸を用いた場合は鉄がほとんど捕集されなかつ たことである。TE-08樹脂は $\mathrm{Fe}^{3+}$ に選択性を持つ。塩酸で の分解時に過酸化水素を添加し, $\mathrm{Fe}^{2+}$ の酸化を促進したと ころ，鉄はほぼ $100 \%$ 捕集された。このことから，通常の塩 酸分解で生じた主成分の $\mathrm{Fe}^{2+}$ は捕集しなかったものと考 えられる。一方, 硝酸, 塩酸・硝酸混合溶液および過塩素 酸の場合鉄はほぼ $100 \%$ 捕集されることが確認できた。

添加元素の分析に関して, 塩酸 ・硝酸混合溶液を用いた 場合が最も多種元素の分析が可能であった。 Si, P, Tiに関し

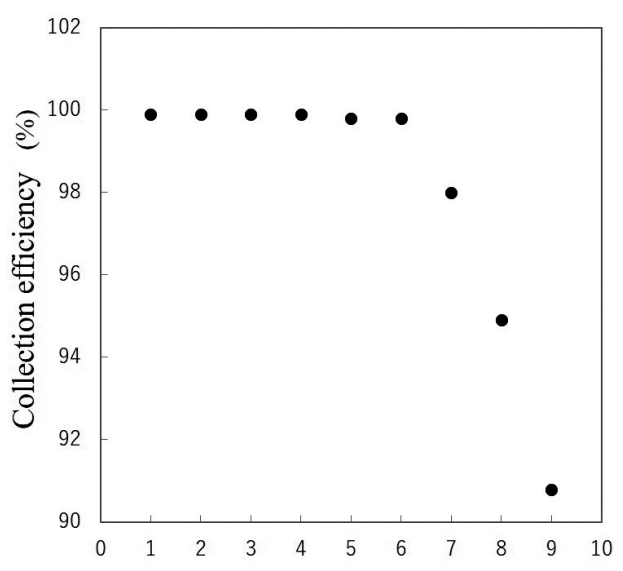

Amount of $\mathrm{Fe}$ in $10 \mathrm{~cm}^{3}$ solution (mg)

Fig. 1. Collection rate of iron using the solid phase extraction resin. The sample solutions were containing total amounts of $1 \mathrm{~mol} / \mathrm{dm}^{3}$ of mixed acid, which was a mixture of $\mathrm{HCl}$ and $\mathrm{HNO}_{3}$ in a volume ratio of 1:1. Flow rate on the solid phase extraction was $0.5 \mathrm{~cm}^{3} / \mathrm{min}$. 
ては, 通液により過剩量の溶出が認められた。これは, 基 材のシリカなどの固相樹脂由来の成分が溶出しているもの と考えられる。そのため，これらの元素の分析では，固相 樹脂のコンディショニング法など，さらなる検討が必要で ある。㘯のほかの元素に関しては，酸種に関係なく捕集さ れない元素が $\mathrm{Mn}, \mathrm{Ni}, \mathrm{Cu}, \mathrm{Co}, \mathrm{Al}, \mathrm{B}, \mathrm{Mg}, \mathrm{Ce}, \mathrm{La}, \mathrm{Te}, \mathrm{Zn}, \mathrm{Cd}$, 酸種により捕集収状況が変化する元素が $\mathrm{Cr}, \mathrm{Bi}, \mathrm{Pb}$, 鉄と同 様樹脂に捕集される元素が Mo, W, V, As, Nb, Sb, Sn, Ta, Zr であった。鉄と同時に捕集されるこれらの元素は，オキソ 酸やクロロ酸錯体のような陰イオンとして溶液中に存在す る元素が多数を占めて打り，この樹脂では鉄と同時に陰イ オンも捕集されることが見いだされた。

\section{$3 \cdot 3$ 酸濃度の検討}

酸種の検討において, 塩酸・硝酸混合溶液を用いた場合 に最も多くの元素が分析可能であった。一方，固相樹脂の 再生には塩酸を用いている。この両者を用いて，固相樹脂 への各元素の捕集率と酸濃度との関係を検討した。試駼溶 液は JSS003-7 試料 $25 \mathrm{mg}$ に各元素濃度が $1 \mu \mathrm{g} / \mathrm{g}$ となるよう 標準液を添加し, 最終濃度が塩酸・硝酸混合溶液は塩酸と 硝酸の合計のモル濃度が $0.1,0.5,1,2,3,4 \mathrm{~mol} / \mathrm{dm}^{3}$, 塩酸で は $0.5,1,2,3,4,5,6 \mathrm{~mol} / \mathrm{dm}^{3}$ となる量で酸分解を行い, 50 $\mathrm{cm}^{3}$ に定容した。な打，塩酸・硝酸混合溶液濃度の増加に より固相樹脂が分解されるため, $5 \mathrm{~mol} / \mathrm{dm}^{3}$ 以上の塩酸・硝 酸混合溶液での検討は行わなかった。その結果をFig.2に 示す。

塩酸・硝酸混合溶液では，主成分の鉄はすべての濃度に おいてほぼ100\%樹脂に捕集され，樹脂通過後の溶液でも ほぼ検出されなかった。一方，塩酸を用いた場合では，濃 度が高くなると鉄の捕集率は低下した。3・2で述べたと招 り, 通常の塩酸分解時に打いては $\mathrm{Fe}^{2+}$ から $\mathrm{Fe}^{3+}$ への酸化が 不十分であるため，残存する 2 価成分が捕集率を低下させ た要因であると考えられる。

塩酸・硝酸混合溶液に打いて, 濃度に関係なくほほ捕集 されない元素が $\mathrm{Mn}, \mathrm{Ni}, \mathrm{Cu}, \mathrm{Co}, \mathrm{Al}, \mathrm{B}, \mathrm{Bi}, \mathrm{Mg}, \mathrm{La}, \mathrm{Pb}, \mathrm{Te}, \mathrm{Zn}$, $\mathrm{Cd}$ ，濃度に関係なくほぼ全量捕集される元素が $\mathrm{Mo}, \mathrm{W}, \mathrm{Nb}$,
$\mathrm{Sn}, \mathrm{Ta}, \mathrm{Zr}$, 濃度が $0.1 \mathrm{~mol} / \mathrm{dm}^{3}$ と低い場合に捕集されない元 素が $\mathrm{Cr}, \mathrm{V}, \mathrm{As}, \mathrm{Sb}$ ，濃度が $1 \mathrm{~mol} / \mathrm{dm}^{3}$ 程度で半量ほど捕集さ れる元素が $\mathrm{Ce}, \mathrm{Sb}$ ，となった。

塩酸に打いて, 濃度に関係なくほぼ捕集されない元素が $\mathrm{Mn}, \mathrm{Ni}, \mathrm{Cr}, \mathrm{Cu}, \mathrm{Co}, \mathrm{Al}, \mathrm{B}, \mathrm{Bi}, \mathrm{Mg}, \mathrm{La}, \mathrm{Pb}, \mathrm{Te}, \mathrm{Zn}, \mathrm{Cd}$, 濃度に 関係なくほぼ全量捕集される元素が $\mathrm{W}, \mathrm{Ta}, \mathrm{Zr}$, 濃度に関係 なくほぼ半量近く捕集される元素が $\mathrm{Nb}$ ，濃度が高くなる と捕集されない元素が $\mathrm{Mo}, \mathrm{Ce}, \mathrm{Sb}, \mathrm{Sn}$, 濃度が高くなると捕 集される元素がAsとなった。

鉄イオンの酸化状態により捕集率が変化する点および As Seの揮発という問題から, 分解には濃度 $1 \mathrm{~mol} / \mathrm{dm}^{3}$ 以 上の塩酸・硝酸混合溶液を用いることとした。

\section{$3 \cdot 4$ 固相樹脂の再生}

固相樹脂使用後の洗浄が十分ではない場合, 鉄の捕集容 量の減少が懸念される。加えて, 分析成分が樹脂中に残存 することにより，次に処理したサンプルに污染が生じる恐 れもある。固相樹脂の洗浄効果を確認するため, JSS003-7 試料 $25 \mathrm{mg}$ を最終濃度が $1 \mathrm{~mol} / \mathrm{dm}^{3}$ となる量の塩酸・硝 酸混合溶液を用いて分解し，各種元素を添加したのち 50 $\mathrm{cm}^{3}$ に定容した溶液 $10 \mathrm{~cm}^{3}$ で捕集操作を行った。その後, 6 $\mathrm{mol} / \mathrm{dm}^{3}$ 塩酸 $10 \mathrm{~cm}^{3}$ と EDTA二アンモニゥム塩 $10 \mathrm{~g} / \mathrm{dm}^{3}$ 溶 液 $10 \mathrm{~cm}^{3}$ をそれぞれ通液後, 回収し, 各元素を測定して洗 浄効果を検証した。

鉄に関して，固相樹脂通液後の $6 \mathrm{~mol} / \mathrm{dm}^{3}$ 塩酸には捕集 量の $22.7 \%$, 通液後の EDTA二アンモニウム溶液には $96.8 \%$ が固相樹脂より溶出しており, EDTA二アンモニウム溶液 の方が洗浄効果は高いことが分かった。加えて, 鉄の捕集 操作を行った後, $6 \mathrm{~mol} / \mathrm{dm}^{3}$ 塩酸溶液での久固相樹脂を洗浄 し，再度鉄を捕集した場合の再捕集率は $95 \%$, EDTA二ア ンモニゥム溶液でのみ洗浄した場合の再捕集率は $98 \%$, 両 者を併用した場合の再捕集率はほぼ $100 \%$ であった。この ことから，塩酸, EDTA二アンモニウム溶液での二段階の 洗浄によって，固相樹脂の再生が問題なく行えていること が確認できた。

塩酸・硝酸混合溶液を用いた場合に捕集されない元素

Table 2. Collection rates of trace elements using the solid phase extraction resin.

\begin{tabular}{|c|c|c|c|c|c|c|c|c|c|c|c|c|c|c|}
\hline & $\mathrm{Fe}$ & $\mathrm{Si}$ & $\mathrm{Mn}$ & $\mathrm{P}$ & $\mathrm{Ni}$ & $\mathrm{Cr}$ & Mo & $\mathrm{Cu}$ & $\mathrm{W}$ & $\mathrm{V}$ & $\mathrm{Co}$ & $\mathrm{Ti}$ & $\mathrm{Al}$ & As \\
\hline $\mathrm{HCl}$ & $x$ & - & $\square$ & - & $\square$ & $x$ & () & $x$ & () & $\triangle$ & $\square$ & - & $\triangle$ & 0 \\
\hline $\mathrm{HNO}_{3}$ & (2) & - & $x$ & - & $x$ & $\square$ & (O) & $x$ & (2) & (0) & $\square$ & - & $\triangle$ & () \\
\hline Mixed acid* & () & - & $\square$ & - & $\times$ & $\square$ & (2) & $\times$ & () & () & $\square$ & - & $\square$ & () \\
\hline \multirow[t]{2}{*}{$\mathrm{HClO}_{4}$} & () & - & $\square$ & - & ( & () & () & $\square$ & () & ( & $\square$ & - & $\square$ & $\times$ \\
\hline & $\mathrm{B}$ & $\mathrm{Bi}$ & $\mathrm{Mg}$ & $\mathrm{Ce}$ & $\mathrm{La}$ & $\mathrm{Nb}$ & $\mathrm{Pb}$ & $\mathrm{Sb}$ & $\mathrm{Sn}$ & $\mathrm{Ta}$ & $\mathrm{Te}$ & $\mathrm{Zn}$ & $\mathrm{Zr}$ & $\mathrm{Cd}$ \\
\hline $\mathrm{HCl}$ & $\times$ & $x$ & $\times$ & $\triangle$ & $\times$ & $\triangle$ & $x$ & () & () & () & $x$ & $\times$ & 0 & $\times$ \\
\hline $\mathrm{HNO}_{3}$ & $\times$ & () & $\times$ & 0 & $\times$ & () & $\square$ & () & () & () & $x$ & $\times$ & () & $x$ \\
\hline Mixed acid* & $\times$ & $\square$ & $\times$ & $\triangle$ & $\times$ & () & $\square$ & (C) & () & () & $\times$ & $\times$ & () & $\times$ \\
\hline $\mathrm{HClO}_{4}$ & $\times$ & () & $\times$ & $\square$ & $\square$ & ( ) & 0 & $\times$ & () & $\bigcirc$ & $\times$ & $\times$ & () & $\square$ \\
\hline
\end{tabular}

(): $95 \% \sim 0: 80 \sim 95 \% \triangle: 30 \sim 80 \%$ 口: $10 \sim 30 \% \times: \sim 10 \%-:$ Over detection

* The mixed acid is the same as in Fig. 1.

The concentrations of each acid was $1 \mathrm{~mol} / \mathrm{dm}^{3}$. The sample solutions were containing $500 \mathrm{mg} / \mathrm{dm}^{3} \mathrm{Fe}$ and $0.5 \mu \mathrm{g} / \mathrm{dm}^{3}$ each element. 
(Mn, Ni, Cu, Co, Al, B, Bi, Mg, La, Pb, Te, Zn, Cd) は，この 洗浄操作後の再生樹脂を用いた場合であっても分析值の 変化はなかった。鉄とともに捕集される微量元素のうち, $\mathrm{Ce}, \mathrm{Sb}, \mathrm{Cr}, \mathrm{V}, \mathrm{As}$ および $\mathrm{Sb}$ は洗浄操作を行うことで, 固相 樹脂よりほぼ全量溶出させることができた。また, Sn は塩 酸溶液のみで, Wおよび Zr は EDTA 溶液のみで, 固相樹脂 よりほぼ $100 \%$ 溶出させることが可能であった。一方，両 者を併用した場合でもMoは約60\%にとどまり, Nb および
Taに対して全く洗浄効果は認められなかった。しかし, 洗 浄後の固相樹脂において, これらの元素が他の測定対象元 素の分析に影響を与えることはなかった。これらの結果か ら, $6 \mathrm{~mol} / \mathrm{dm}^{3}$ 塩酸およびEDTAアンモニウム溶液での洗浄 を併用することにより，固相樹脂の再生再利用が可能であ ると考えられる。今回用いた固相樹脂は洗浄再生操作によ り 30 回以上の繰り返し使用できることを確認して扣り, 有 用な特徵だと考えられる。

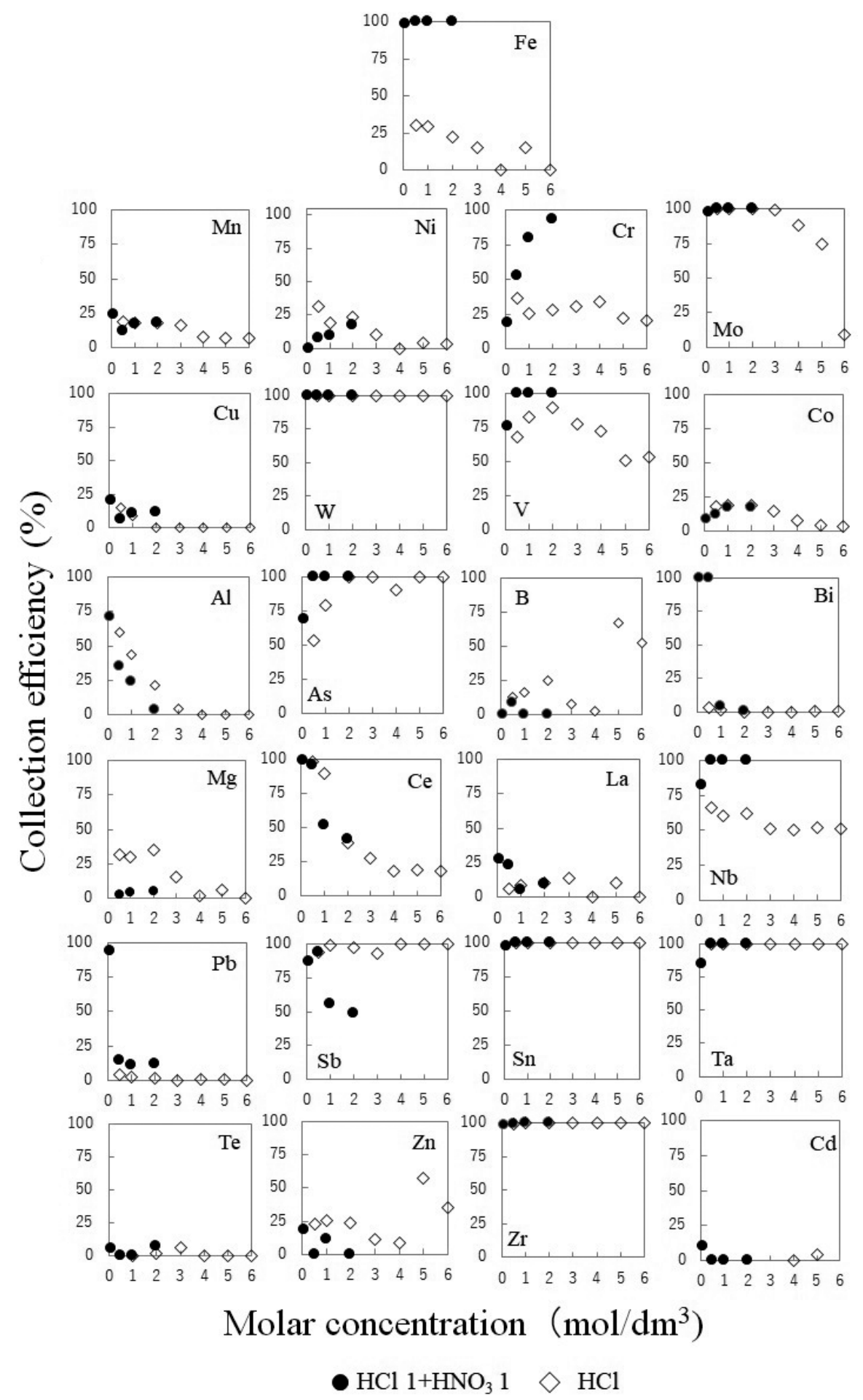

Fig. 2. Effect of the acid concentration on collection rates of trace elements using the solid phase extraction resin. The kinds of the acid were $\mathrm{HCl}$ (closed circle), and the mixed acid (open diamond) same as Fig. 1. Other conditions are the same as in Table 2. 


\section{$3 \cdot 5$ 定量分析精度の検討}

以上の検討結果を踏まえ, 塩酸・硝酸混合溶液濃度を 1 $\mathrm{mol} / \mathrm{dm}^{3}$ として検量線溶液を調製し, JSS003-7 分解溶液を 用いて, 絶対検量線法により各元素 $(\mathrm{Mn}, \mathrm{Ni}, \mathrm{Cu}, \mathrm{Co}, \mathrm{Al}, \mathrm{As}$, $\mathrm{B}, \mathrm{Bi}, \mathrm{Cd}, \mathrm{Ce}, \mathrm{La}, \mathrm{Mg}, \mathrm{Pb}, \mathrm{Sb}, \mathrm{Te}, \mathrm{Zn})$ の分析精度の確認を 行った。樹脂捕集率が $0 \%$ でない元素もあるため, 本検討 においては検量線溶液に対し，捕集操作を行わなかったも の (未捕集検量線) と捕集操作を行ったもの（捕集検量線） で検量線をそれぞれ作成し，両方の分析結果を比較した。 一連の操作では, $1 \mathrm{~mol} / \mathrm{dm}^{3}$ 塩酸・硝酸混合溶液を用いて 捕集操作をおこなった溶液の結果をブランク量として分析 結果より差し引いた。両検量線の比較打よび捕集検量線を 用いて求めた検出限界, 定量限界を Fig. 3 に示す。横軸は鉄 中の各元素の含有量と換算して表記した。検出限界 (DL), 定量限界 $(\mathrm{QL})$ の算出は以下の計算式を用いた。
検出限界 (DL) : $3.3 \sigma \mathrm{BL} / \mathrm{a}$

定量限界 (QL) : $10 \sigma \mathrm{BL} / \mathrm{a}$

ただし, $\sigma \mathrm{BL}:$ ブランクの標準偏差

\section{$\mathrm{a}:$ 検量線の傾き}

$\mathrm{Mn}, \mathrm{Ni}, \mathrm{Cu}$ な゙のようにそれぞれの検量線に大差ないも のもあるが, $\mathrm{Ce}, \mathrm{Sb}$ など捕集検量線の傾きが低くなってい る元素もあった。Bに関しては感度不足のため, 検量線作 成ができなかった。定量限界值は, $\mathrm{Al}, \mathrm{As}, \mathrm{Te}$ など感度の低 い元素では打よそ $0.2 \mu \mathrm{g} / \mathrm{g}$ となっているが，ほとんどの元 素で日本鉄鋼認証標準物質高純度鉄の不純物元素の表示 領域である $0.1 \mu \mathrm{g} / \mathrm{g}$ での分析が可能であることが確認でき た。それぞれの検量線を用いてJSS003-7 分解溶液を分析し た結果を Table 3 に示す。検出できなかった元素に関しては 定量限界值を求め, それ以下の表記とした。捕集検量線,

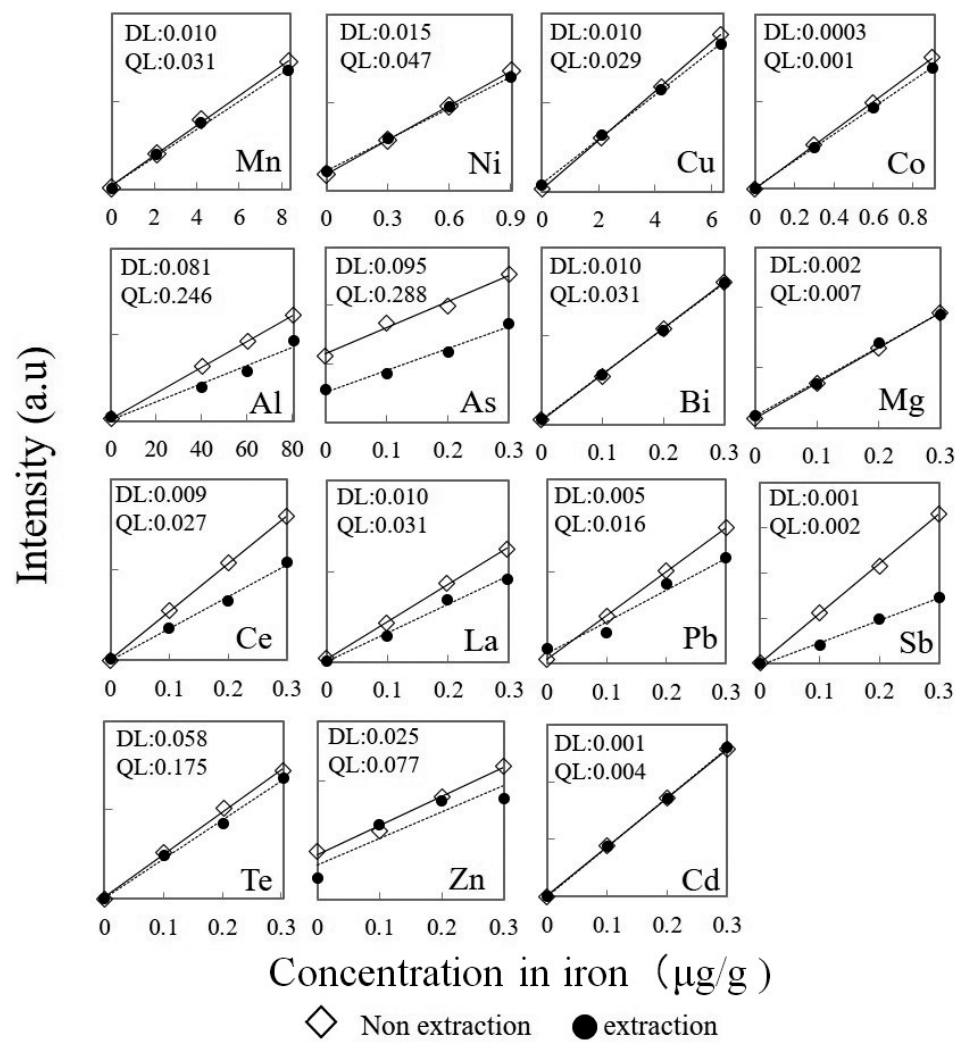

Fig. 3. Calibration curves of trace elements in $1 \mathrm{~mol} / \mathrm{dm}^{3}$ mixed acid (same as Fig. 1). With (closed circle), and without (open diamond) the solid phase extraction.

Table 3. Analytical results of trace elements in high-purity iron (JSS 003-7) using sample solutions containing $1 \mathrm{~mol} / \mathrm{dm}^{3}$ of mixed acid of $\mathrm{HCl}$ and $\mathrm{HNO}_{3}$ with 1:1 volume ratio.

\begin{tabular}{c|c|cccccccccccccccc}
\hline \multicolumn{2}{c|}{} & $\mathrm{Mn}$ & $\mathrm{Ni}$ & $\mathrm{Cr}$ & $\mathrm{Cu}$ & $\mathrm{Co}$ & $\mathrm{Al}$ & $\mathrm{As}$ & $\mathrm{Bi}$ & $\mathrm{Mg}$ & $\mathrm{Ce}$ & $\mathrm{La}$ & $\mathrm{Pb}$ & $\mathrm{Sb}$ & $\mathrm{Te}$ & $\mathrm{Zn}$ & $\mathrm{Cd}$ \\
\hline \multicolumn{2}{c}{\begin{tabular}{c} 
Certified value $(\mu \mathrm{g} / \mathrm{g})$ \\
\multicolumn{2}{c}{ Uncertainty }
\end{tabular}} & 5.4 & 0.7 & 1.3 & 3.2 & 0.47 & 68.2 & $<1$ & 0.18 & $<1$ & $<0.5$ & $<0.5$ & $0.02^{*}$ & $<2$ & $<1$ & $0.2^{*}$ & $<0.5$ \\
\hline \multirow{2}{*}{ Non extraction } & 0.2 & 0.2 & 0.4 & 0.2 & 0.04 & 3.9 & - & 0.06 & - & - & - & - & - & - & - & - \\
\hline \multirow{2}{*}{ extraction } & Found $(\mu \mathrm{g} / \mathrm{g})$ & 4.9 & 0.6 & 0.3 & 3.2 & 0.39 & 73.4 & $<0.15$ & $<0.05$ & 0.16 & $<0.05$ & 0.11 & 0.03 & 0.005 & $<0.2$ & 0.13 & 0.009 \\
& $\mathrm{RSD}(\mathrm{N}=3)$ & 1.7 & 21.8 & 4.9 & 7.5 & 4.2 & 9.3 & 2.9 & 35.2 & 24.8 & 29.6 & 15.2 & 3.5 & 42.9 & 39.1 & 27.6 & 6.3 \\
\hline & Found $(\mu \mathrm{g} / \mathrm{g})$ & 5.7 & 0.5 & 0.12 & 3.7 & 0.51 & 69.6 & $<0.3$ & $<0.04$ & 0.08 & $<0.03$ & $<0.03$ & 0.02 & 0.009 & $<0.2$ & 0.16 & 0.010 \\
& $\mathrm{RSD}(\mathrm{N}=3)$ & 1.2 & 2.2 & 6.8 & 15.2 & 1.2 & 4.1 & 2.9 & 27 & 13.2 & 27.5 & 77.7 & 19.6 & 2.9 & 57.1 & 10.5 & 7.1 \\
\hline
\end{tabular}


未捕集検量線のそれぞれから得られた各元素の分析値に ついて検定を行ったところ，有意差のなかった元素が $\mathrm{Ni}$, $\mathrm{Cu}, \mathrm{Al}, \mathrm{Mg}, \mathrm{Zn}, \mathrm{Cd}$, 有意差のあった元素が $\mathrm{Mn}, \mathrm{Co}, \mathrm{Pb}, \mathrm{Sb}$ で あった。有意差のあった元素では，捕集検量線より得られ た分析值が認証值とよく一致した。この結果から，有意差 のあった元素打よび未検出の元素に関しては捕集検量線の 作成が必要と考えられる。

\section{$3 \cdot 6$ クロムの検討}

$3 \cdot 3$ で述べたとおり $\mathrm{Cr}$ に関しては $0.1 \mathrm{~mol} / \mathrm{dm}^{3}$ といっ た低酸濃度での捕集率が低いことから，塩酸・硝酸混合 溶液濃度 $0.1 \mathrm{~mol} / \mathrm{dm}^{3}$ の検量線溶液を調製し, 他元素同様, 未捕集，捕集検量線での比較結果およびJSS003-7を分析 した。その結果を Fig.4 およびTable 4 に示す。これらの結 果により, 塩酸・硝酸混合溶液濃度を低下させれば, Crに 関しても認証值と同等の值が得られることが確認できた。 Fig.2に示すように, Crは今回検討した元素の中でも, 塩酸 と塩酸・硝酸混合溶液とで大きな差が見られる特徵的な元 素である。クロムの電位-pH図を参照 ${ }^{25}$ すると $1 \mathrm{~mol} / \mathrm{dm}^{3}$ の 塩酸中では $\mathrm{Cr}^{3+}$ の状態にあると考えられる。一方, 硝酸存 在中で加熱分解を行う場合は, $\mathrm{Cr}^{3+}$ から $\mathrm{Cr}_{2} \mathrm{O}_{7}{ }^{2-}$ へと酸化 されている。これらのことから，塩酸を用いた場合では陽 イオンの $\mathrm{Cr}^{3+}$ で存在するため, クロムは捕集されず, 一方

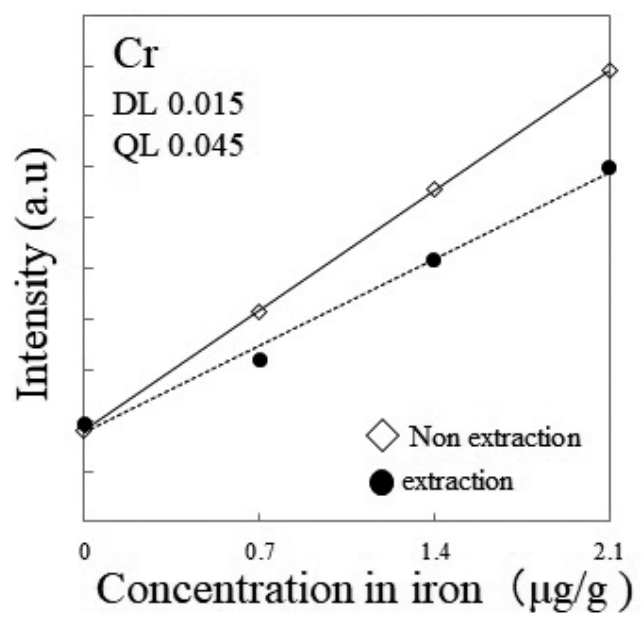

Fig. 4. Calibration curves of $\mathrm{Cr}$ in $0.1 \mathrm{~mol} / \mathrm{dm}^{3}$ mixed acid (same as Fig. 1). With (closed circle), and without (open diamond) the solid phase extraction.

Table 4. Analytical results of Cr in high-purity iron (JSS 0037) using sample solutions containing $0.1 \mathrm{~mol} / \mathrm{dm}^{3}$ of mixed acid of $\mathrm{HCl}$ and $\mathrm{HNO}_{3}$ with 1:1 volume ratio.

\begin{tabular}{|c|c|c|c|}
\hline \multicolumn{2}{|c|}{ molar concentration } & 1 & 0.1 \\
\hline \multicolumn{2}{|c|}{ Cr Certified value $(\mu \mathrm{g} / \mathrm{g})$} & \multicolumn{2}{|c|}{1.3} \\
\hline \multicolumn{2}{|c|}{ Uncertainty } & \multicolumn{2}{|c|}{0.4} \\
\hline \multirow{2}{*}{ Non extraction } & Found $(\mu \mathrm{g} / \mathrm{g})$ & 0.3 & 1.4 \\
\hline & $\operatorname{RSD}(\mathrm{N}=3)$ & 4.9 & 12.5 \\
\hline \multirow{2}{*}{ extraction } & Found $(\mu \mathrm{g} / \mathrm{g})$ & 0.12 & 1 \\
\hline & $\operatorname{RSD}(\mathrm{N}=3)$ & 6.8 & 6.8 \\
\hline
\end{tabular}

塩酸·硝酸混合溶液では, 硝酸により酸化された $\mathrm{Cr}_{2} \mathrm{O}_{7}^{2-}$ が, 陰イオンを捕集する特徵のあるこの樹脂に優先的に捕集さ れる。また $1 \mathrm{~mol} / \mathrm{dm}^{3}$ と $0.1 \mathrm{~mol} / \mathrm{dm}^{3}$ の塩酸・硝酸混合溶液 の間で捕集率に大きな差が生じているのは, 硝酸量によっ て酸化されるクロム量が異なるためであると考えられる。

\section{$3 \cdot 7$ セレンの検討}

よく知られているように，セレンはプラズマガス元素で ある $\operatorname{Ar}$ の複合イオンによる干渉を受けるため ${ }^{26)}$ ，通常の 測定では分析できない。そのため, コリジョン・リアクショ ンセルを用いて干渉除去を行い, 分析を実施した。 $1 \mathrm{~mol} /$ $\mathrm{dm}^{3}$ 濃度の塩酸・硝酸混合溶液による未捕集打よび捕集検 量線を Fig.5に示す。JSS003-7を分析した結果，検出限界の $0.2 \mu \mathrm{g} / \mathrm{g}$ 未満となった。コリジョン・リアクションセルに よる感度低下のため検出限界が $0.2 \mu \mathrm{g} / \mathrm{g}$ と高くなっている が，JSS003-7の認証值 $1 \mu \mathrm{g} / \mathrm{g}$ 未満であることが確認できた。 より高感度な分析が必要な場合, 試料量および樹脂容量を 増やすなどの対応が必要となる。

\section{$3 \cdot 8$ 過塩素酸分解での検討}

一般的な鉄鋼材料の分析に打いては, 塩酸・硝酸混合溶 液では完全に分解されず, 残渣が生じるため, 分析值に影 響を与える場合がある。今回の一連の研究では，そのよう な残椬は目視打よびろ過操作では確認されなかったが，分 解が不十分である可能性も考慮して, JSS003-7の過塩素酸 分解についても検討した。分解に際しては石英ビーカーを 用い, $12 \mathrm{~cm}^{3}$ の王水で分解したのち, 過塩素酸を加え, 白 煙発生まで加熱したのち, 最終の酸濃度を $1 \mathrm{~mol} / \mathrm{dm}^{3}$ に調 製して分析した。未捕集，捕集検量線でのJSS003-7の分析 結果を Table 5 に示す。過塩素酸溶液では, 塩酸・硝酸混合 溶液で分析が可能であった $\mathrm{As}, \mathrm{Bi}, \mathrm{Sb}, \mathrm{Pb}, \mathrm{La}$ は樹脂捕集率 が高く,良好な検量線が得られなかったため，分析できな かった。また, $\mathrm{Mg}$ など一部元素の定量下限, 検出限界が高 くなるなど, 塩酸・硝酸混合溶液と比較してバックグラウ

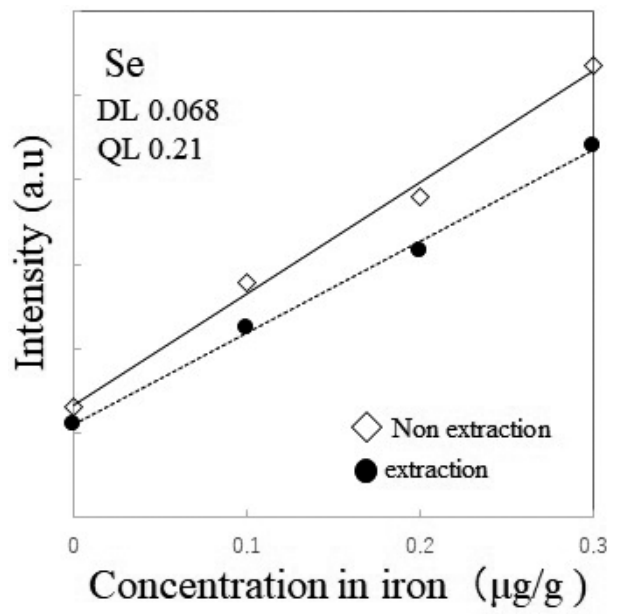

Fig. 5. Calibration curves of Se in $1 \mathrm{~mol} / \mathrm{dm}^{3}$ mixed acid (same as Fig. 1). With (closed circle), and without (open diamond) the solid phase extraction. 
Table 5. Analytical results of trace elements in of high-purity iron (JSS 003-7) using sample solutions containing $1 \mathrm{~mol} / \mathrm{dm}^{3}$ of Perchloric acid.

\begin{tabular}{c|c|cccccccccc}
\hline \multicolumn{2}{c|}{} & $\mathrm{Mn}$ & $\mathrm{Ni}$ & $\mathrm{Cu}$ & $\mathrm{Co}$ & $\mathrm{Al}$ & $\mathrm{Ce}$ & $\mathrm{Mg}$ & $\mathrm{Te}$ & $\mathrm{Zn}$ & $\mathrm{Cd}$ \\
\hline \multicolumn{2}{c}{ Certified value $(\mu \mathrm{g} / \mathrm{g})$} & 5.4 & 0.7 & 3.2 & 0.47 & 68.2 & $<0.5$ & $<1$ & $<1$ & $0.2^{*}$ & $<0.5$ \\
\multicolumn{2}{c}{ Uncertainty } & 0.2 & 0.2 & 0.2 & 0.04 & 3.9 & - & - & - & - & - \\
\hline \multirow{2}{*}{ Non extraction } & Found $(\mu \mathrm{g} / \mathrm{g})$ & 4.8 & 0.7 & 2.9 & 0.47 & 65.3 & 0.033 & $<1$ & $<0.09$ & 0.13 & $<0.05$ \\
& $\mathrm{RSD}(\mathrm{N}=3)$ & 13.7 & 49.6 & 36 & 12.7 & 6.6 & 4.0 & 15.5 & 7.3 & 10.0 & 75.7 \\
\hline \multirow{2}{*}{ extraction } & Found $(\mu \mathrm{g} / \mathrm{g})$ & 5.2 & 1 & 3.2 & 0.48 & 75.8 & 0.080 & $<0.7$ & $<0.04$ & 0.23 & $<0.03$ \\
& RSD $(\mathrm{N}=3)$ & 7.9 & 28.1 & 14 & 7.7 & 6.4 & 40.1 & 63.6 & 5.7 & 6.3 & 56 \\
\hline
\end{tabular}

ンドの值が高くなる傾向が見られた。これは，塩酸・硝酸 混合溶液に使用したUltrapureグレードの塩酸, 硝酸に比べ て, 過塩素酸の純度の影響があること, また, 過塩素酸自 体の粘性により，吸引量が低下したためであると考えられ る。他の測定可能であった元素に関しては塩酸・硝酸混合 溶液同様の良好な值が得られたことから, 高純度鉄の分析 の際には難溶性残椬の影響は小さく無視できるものと考え られる。

\section{4. 結言}

分析のスキリフリー化, 簡便化を目指して鉄高選択性固 相抽出固相樹脂を用いて高純度鋼中の各元素の定量分析 を試み, 鉄量, 酸の種類およびその濃度などの最適条件の 検討を行った。その結果，マトリックスの鉄をほぼ $100 \%$ 樹脂捕集できる条件を見出した。その際, 回収溶液におい て Mn, Ni, Cr, Cu, Co, Al, As, B, Bi, Cd, Ce, La, Mg, Pb, Sb, Te, $\mathrm{Zn}, \mathrm{Se}$ が測定可能であることを確認した。これらの元素は, 認証值に対して十分な精度で分析が可能であり, 高純度鋼

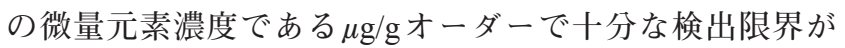
得られることが分かった。今回研究を行った手法は, 固相 樹脂に分解溶液を通液し, 流出した溶液をそのままICPMSにより分析することができる非常に簡便な手法であ る。また, 溶媒抽出などの複雑な操作を必要としないため, 污染対策の面でも非常に有益な手法と考えられる。

\section{文献}

1 ) K.Oguma and N.Uehara: Tetsu-to-Hagané, 100(2014), 818 (in Japanese). https://doi.org/10.2355/tetsutohagane.100.818

2 ) H.Okochi: Materia Jpn., 33(1994), 305 (in Japanese). https://doi. org $/ 10.2320$ /materia.33.305

3 ) H.Asano, H.Itabashi and H.Kawamoto: Tetsu-to-Hagané, 89(2003), 935 (in Japanese). https://doi.org/10.2355/tetsutohagane1955.89.9 935

4 ) T.Taniai, A.Sakuragawa and A.Uzawa: ISIJ Int., 44(2004), 1852. https://doi.org/10.2355/isijinternational.44.1852

5 ) JIS G 1214: 1998, Iron and steel - Methods for determination of phosphorus content (in Japanese).

6 ) K.Fujimoto and M.Shimura: Bunseki Kagaku, 50(2001), 175 (in Japanese). https://doi.org/10.2116/bunsekikagaku.50.175
7 ) S.-i.Hasegawa: Tetsu-to-Hagané, 95(2009), 911 (in Japanese). https:// doi.org/10.2355/tetsutohagane.95.911

8 ) S.-i.Hasegawa: Tetsu-to-Hagané, 100(2014), 884 (in Japanese). https:// doi.org/10.2355/tetsutohagane.100.884

9 ) F.Sakamoto, K.Takada and K.Wagatsuma: Bunseki Kagaku, 54(2005), 1039 (in Japanese). https://doi.org/10.2116/bunsekikagaku. 54.1039

10) S.-i.Hasegawa, T.Kobayashi, K.Sato, S.Igarashi and K.Naito: J. Jpn. Inst. Met, 63(1999), 1069 (in Japanese). https://doi.org/10.2320/ jinstmet1952.63.8_1069

11) H.Matsumiya, S.Furuzawa and M.Hiraide: Anal. Chem, 77(2005), 5344. https://doi.org/10.1021/ac0504114

12) S.-i.Hasegawa, K.Sato, K.Ide, T.Kobayashi, S.Igarashi and K.Naito: $J$. Jpn. Inst. Met, 64(2000), 1212 (in Japanese). https://doi.org/10.2320/ jinstmet1952.64.12_1212

13) Y.Furusho, M.Ono, M.Yamada, K.Ohashi, T.Kitade, K.Kuriyama, S.Ohta, Y.Inoue and S.Motomizu: Bunseki Kagaku, 57(2008), 969 (in Japanese). https://doi.org/10.2116/bunsekikagaku.57.969

14) T.Okano and Y.Matsumura: Tetsu-to-Hagané, 77(1991), 1951 (in Japanese). https://doi.org/10.2355/tetsutohagane1955.77.11_1951

15) JIS G 1257-18-1: 2013, Iron and steel - Atomic absorption spectrometric method - Part 18: Determination of tellurium - Section 1: Flame atomization after extraction of iodide (in Japanese).

16) JIS G 1224: 2001, Iron and steel - Methods for determination of aluminum content (in Japanese).

17) H.Matsunaga: Bunseki Kagaku, 50(2001), 89 (in Japanese). https:// doi.org/10.2116/bunsekikagaku.50.89

18) T.Seki, H.Takigawa, Y.Hirano, Y.Ishibashi and K.Oguma: Anal. Sci., 16(2000), 513. https://doi.org/10.2116/analsci.16.513

19) K.Hanada, Y.Kajima, K.Fujimoto, M.Shimura and S.Satoh: Tetsuto-Hagané, 89(2003), 895 (in Japanese). https://doi.org/10.2355/ tetsutohagane1955.89.9_895

20) K.Hanada, K.Fujimoto, M.Shimura and K.Yoshioka: Bunseki Kagaku, 46(1997), 749 (in Japanese). https://doi.org/10.2116/bunsekikagaku. 46.749

21) K.Fujimoto, K.Hanada, M.Shimura and K.Yoshioka: Materia Jpn., 38(1999), 163 (in Japanese). https://doi.org/10.2320/materia.38.163

22) K.Kitada, A.ITO, J.Aizawa and T.Umita: J. Jpn. Sewage Works Assoc., 35(1998), 143 (in Japanese).

23) J.Takahashi and N.Yamada: Bunseki Kagaku, 53(2004), 1257 (in Japanese). https://doi.org/10.2116/bunsekikagaku.53.1257

24) AnaLig-IBC, IBC Advanced Technologies, http://www.ibcmrt.com/ products/analig/, (accessed 2021-05-14).

25) M.Pouebaix: Atlas of Electrochemical Equilibra in Aqueous Solutios, National Association of Corrosion Engineers, Houston, TX, (1974), 256.

26) B.Hattendorf and D.Gunther: Spectochim. Acta Part B, 58(2003), 1. 